\title{
РАЗВИТИЕ НОРМАТИВНО-ПРАВОВОЙ БАЗЫ РЕЖИМОВ ЧРЕЗВЫЧАЙНОГО И ВОЕННОГО ПОЛОЖЕНИЯ
}

\begin{abstract}
Аннотация: Статья посвящена исследованию отечественной нормативно-правовой базы, регламентирующей установление административно-правовых режимов на примере таких разновидностей, как режимы чрезвычайного и военного положения, которые берут свое начало ещуе в дореволюиионной и советской России. Характеризуя современный этап развития законодательства об административно-правовых режимах, в качестве источников рассматриваются Конституцуия РФ, отдельные общепризнанные акты международного характера, спецчиальные и общие тематические законы, а также подзаконные акты.
\end{abstract}

Ключевые слова: административно-правовой режим, режимы чрезвычайного и военного положения

B юридической литературе под административно-правовым режимом понимается «сочетание административно-правовых средств регулирования, опосредованное централизованным порядком, императивным методом юридического воздействия, которое выражается в том, что субъекты правоотношений по своему статусу занимают юридически не равные позиции» ${ }^{1}$; «средство обеспечения публичных интересов в рамках предмета административного права на тех участках социальной деятельности, где необходима целостная система регулятивного воздействия ${ }^{2}$; «общий режим деятельности субъектов исполнительной власти, который регламентирует типичные управленческие отношения» ${ }^{3}$.

Сущность административных режимов заключена в природе самого управления. Нельзя построить даже минимально эффективную систему управления, не осуществив при этом режимную организацию ее основных компонентов ${ }^{4}$.

Обобщенно говоря, административно-правовой режим как разновидность родового понятия «правовой режим» представляет собой совокупность юридических средств регулирования, присущих отрасли административного права, опосредующих специфический порядок деятельности субъектов исполнительной власти в разных сферах государственной жизни. Основу административно-правового режима составляет «совокупность норм административного права, содержащих дозволения, за-

\footnotetext{
${ }^{1}$ Бахрах Д.Н. Административное право: Учебник для вузов. М.: Бек, 1996. С. 202.

${ }^{2}$ Благов А.Д. сущность и особенности административно-правового режима // Известия ИЭГА. 2007. №2 (52). С. 128.

${ }^{3}$ Попова Н.Ф. О классификации специальных административноправовых режимов // Вестник РГГУ. 2008. № 5. С. 39.

${ }^{4}$ Агабалаев М.И. Особенности классификации административноправовых режимов обеспечения общественной безопасности // Современная наука: Актуальные проблемы теории и практики. 2012. №1. C. 13-15.
}

преты и предписания, подлежащие неукоснительному соблюдению субъектами управления» ${ }^{5}$. То есть, содержание административно-правовых режимов определяется совокупностью правил, урегулированных нормами административного права.

Ставя вопрос о развитии законодательной базы административно-правовых режимов, нельзя не отметить видового многообразия последних. С этим связано существование в науке административного права различных точек зрения относительно классификации административно-правовых режимов.

Так, одни исследователи ${ }^{6}$ считают целесообразным выделять: административно-правовые режимы, связанные с установлением определенных государственных состояний (чрезвычайного, военного положения, охраны государственных границ, таможенных границ, регулирования внешнеторговой деятельности и др.); призванные обеспечивать функции управления и сферы деятельности (налоговой, санитарной, экологической и т.д.); легализующие режимы, касающиеся как официальной регистрации юридических и физических лиц, так и регламентации нормативных требований к видам деятельности.

Другие ${ }^{7}$ говорят о существовании - общего отраслевого административно-правового режима; режимов отраслей государственного управления и специальных административно-правовых режимов. Третьи ${ }^{8}$ приводят классификацию основных видов специальных административно-правовых режимов.

Ввиду того, что в рамках одной статьи невозможно в полном объеме охватить законодательную базу многообразных административно-правовых режимов, рассмотрим этот вопрос на примере становления и развития законода-

\footnotetext{
${ }^{5}$ Там же.

${ }^{6}$ См.: Тихомиров Ю.А. Административное право и процесс: полный курс. М.: Изд-во Тихомирова М.Ю., 2005. С. 540.

${ }^{7}$ См.: Попова Н.Ф. Указ. соч. С. 40.

${ }^{8}$ См.: Четвериков В.С. Административное право. Ростов-на-Дону, 2004. $512 \mathrm{c}$.
} 


\section{Право и политика $1(157) \cdot 2013$}

тельства основных специальных режимов - чрезвычайного и военного положений.

История развития законодательной базы режима чрезвычайного положения берет свое начало еще в дореволюционной России, где состояние усиленной (чрезвычайной) охраны было установлено в 1881 году, вскоре после убийства Александра II. Правовым основанием послужило Положение «О мерах к охранению государственного порядка и общественного спокойствия» ${ }^{9}$, предусматривающее возможность объявления «исключительного положения» в формах «усиленной» или «чрезвычайной» охраны.

В условиях советского режима чрезвычайные меры получили свое развитие в утвержденном ЦИК и СНК СССР 3 апреля 1925 г. Положении «О чрезвычайных мерах охраны революционного правопорядка» ${ }^{10}$. В последующем, в годы Великой Отечественной Войны было разработано и принято Постановление ЦК ВКП(б), Президиума ВС СССР и СНК СССР от 30 июня 1941 г., где указывалось, что учреждается Государственный Комитет Обороны «ввиду создавшегося чрезвычайного положения и в целях мобилизации всех сил народов СССР для проведения отпора врагу, вероломно напавшему на нашу Родину» ${ }^{11}$.

Распад Советского Союза и угроза дальнейшей дезинтеграции Российской Федерации, нарастание общесистемного кризиса, проявляющегося практически во всех сферах общественной, экономической и политической жизни, предопределили все более частое обращение органов государственной власти и управления к институту чрезвычайного положения. Только в период 1988 - 1989 гг. чрезвычайное положение (в той или иной форме) вводилось союзными и республиканскими государственными органами власти и управления более 25 раз ${ }^{12}$.

Однако к моменту первых крупных социальных потрясений выяснилось, что в законодательстве СССР и союзных республик отсутствовали даже нормативные акты, регулирующие отношения в условиях техногенных и природных катастроф. В целях обеспечения постоянной готовности к быстрым и эффективным действиям в случае возникновения чрезвычайной обстановки органы государственной власти вынуждены были с учетом экстремальности ситуации оперативно среагировать на имеющиеся пробелы в законодательстве, заполнить правовой

\footnotetext{
${ }^{9}$ См.: Свод законов Российской империи. Кн. 4. Приложение I к статье 1 (прим. 2). СПб., 1910. С. $121-128$.

${ }^{10}$ См.: Собрание законов и распоряжений Рабоче-крестьянского Правительства Союза ССР. 1925. № 25. Ст. 166 - 167.

${ }^{11}$ См.: Известия ЦК КПСС. 1990. № 6. С. 198.

12 Фомин А.А. Исторические этапы развития чрезвычайного законодательства в России (конец XIX - XX вв.) // История государства и права. 2006. №3. С. 76-84.
}

вакуум самым необходимым комплексом чрезвычайных законодательных актов ${ }^{13}$.

В апреле 1990 года был принят Закон СССР от 03.04.1990 №1408-1«О правовом режиме чрезвычайного положения» ${ }^{14}$, согласно которому чрезвычайное положение на территории союзных, автономных республик либо в их одной отдельной местности мог объявить Верховный совет этой союзной или автономной республики; на всей территории СССР чрезвычайное положение мог объявить Верховный совет СССР. Президент СССР мог вводить чрезвычайное положение в отдельных местностях только с согласия Президиума Верховного совета СССР или Верховного совета союзной или автономной республики.

В мае 1991 г. был принят Закон РФ от 17.05.91 № 1253-1 «О чрезвычайном положении» ${ }^{15}$. А также Постановление Верховного Совета РСФСР от 17 мая 1991 года № 1254-1 «О порядке введения в действие Закона РСФСР «О чрезвычайном положении»») ${ }^{16}$.

В августе 1991 года был принят Указ Президента РСФСР от 20 августа 1991 г. «Обуправлении Вооруженными Силами СССР на территории РСФСР в условиях чрезвычайной ситуации» ${ }^{17}$.

Ровно через десять лет Закон РФ № 1253-1 утратил свое действие в результате подписания Президентом РФ ФКЗ от 30 мая 2001 г. № 3-ФКЗ «О чрезвычайном положении» (в ред. от 07.03.2005) ${ }^{18}$. Данный ФКЗ «О чрезвычайном положении» вводит понятие целей и обстоятельств введения чрезвычайного положения. Чрезвычайное положение вводится для «устранения обстоятельств, послуживших основанием для введения чрезвычайного положения, обеспечения защиты прав и свобод человека и гражданина, защиты конституционного строя Российской Федерации» (ст. 2).

На данный момент в Российской Федерации чрезвычайное положение вводит Президент страны при обстоятельствах, предусмотренных ФКЗ «О чрезвычайном положении», с незамедлительным сообщением об этом Совету Федерации и Государственной Думе.

Что касается режима военного положения, то он нередко вводился на отдельных территориях Российской

\footnotetext{
${ }^{13}$ Правовые проблемы преодоления последствий чернобыльской катастрофы // Государство и право. 1998. № 1. С. 15.

${ }^{14}$ Ведомости Съезда народных депутатов СССР и ВС СССР. 1990. №15. Ст. 250 .

${ }^{15}$ Ведомости Съезда народных депутатов РСФСР и Верховного Совета РСФСР. 1991. №22. Ст.773.

${ }^{16}$ Ведомости Съезда народных депутатов РСФСР и Верховного Совета РСФСР. 1991. №22. Ст.774.

${ }^{17}$ Ведомости Съезда народных депутатов РСФСР и Верховного Совета РСФСР. 1991. N 34. Ст. 1138.

${ }^{18}$ Собрание законодательства РФ. 2001. №23. Ст. 2277; 2005. №10. Ст. 753.
} 
Империи в конце XIX в. и в начале XX в. для нейтрализации как внешних (при объявлении войны или угрозы агрессии), так и внутренних (в случае революционных волнений) угроз ${ }^{19}$.

После Октябрьской революции правовой режим военного положения вводился в период Гражданской и Великой Отечественной войн. В период Гражданской войны и интервенции Советская власть была вынуждена то усиливать, то ослаблять репрессии в зависимости от усиления или ослабления боровшихся с ней сил. Так, Декретом СНК РСФСР от 26 ноября 1917 г. ${ }^{20}$ на осадном положении были объявлены все местности, где появлялись вооруженные отряды.

В СССР институт военного положения получил конституционное установление в Конституции 1938 г., где было закреплено правомочие Президиума Верховного Совета СССР объявлять военное положение в отдельных местностях или по всему Советскому Союзу в интересах обороны страны, обеспечения общественного порядка и государственной безопасности. Указанное право было воплощено в жизнь в Указе Президиума Верховного Совета СССР «О военном положении» от 22 июня 1941 г. $^{21}$ В нем определялись основные меры по обеспечению этого режима: передача полномочий органов государственной власти органам военного управления; расширение подсудности военных трибуналов; повышение ответственности военнослужащих и населения по законам военного времени; существенное ограничение прав и свобод граждан и возложение на них дополнительных обязанностей в целях обеспечения обороны и др. Режим военного положения имел основополагающее значение в районах ведения боевых действий в годы Великой Отечественной Войны.

В законодательстве современной России военное положение рассматривается как особый правовой режим, вводимый на территории РФ или в отдельных ее местностях, в случае агрессии против РФ или непосредственной угрозы агрессии. В отличие от ранее действующего законодательства основаниями введения этого режима являются только причины внешнего характера (факт агрессии или угроза агрессии), представляющие опасность для конституционного строя, суверенитета и территориальной целостности государства. Чрезвычайные обстоятельства, обусловленные внутренними угрозами, служат основаниями введения в стране чрезвычайного положения.

В настоящее время основополагающим правовым актом в сфере установления административно-правовых режимов выступает Конституция РФ.

\footnotetext{
${ }^{19}$ См.: Попова Н.Ф., Попова Н.Н. Специальные административноправовые режимы. Монография. М.: ВНИИ МВД России. 2008. $144 \mathrm{c}$.

${ }^{20}$ Собрание Узаконений РСФСР. 1917. № 4. Ст. 53.

${ }^{21}$ Ведомости Верховного Совета СССР. 1941. № 29.
}

Во-первых, Конституция РФ осуществляет первичную легализацию таких специальных административноправовых режимов как чрезвычайное и военное положение, режимов государственной границы, пограничных зон и др. (ст.ст. 71, 72, 87, 88).

Во-вторых, в Конституции закреплены основополагающие положения и принципы функционирования специальных административно-правовых режимов - основания ограничения прав и свобод (ч. 3 ст. 55), принцип неприкосновенности основных прав и свобод (ч. 3 ст. 56), отнесение специальных режимов к совместному ведению Российской Федерации и субъектов Федерации (п. «б», «з», «к» ст. 72), принцип официального установления (ч. 3 ст. 15, п. «б», «в» ст. 102),

Следует отметить, что указанные положения Конституции РФ базируются на общепризнанных нормах международного права, которые также лежат в основе современного правового регулирования административно-правовых режимов. Среди них следует отметить: Всеобщую декларацию прав и свобод человека (п. 2 ст. 29); Пакт о гражданских и политических правах (п. 3 ст. 12; п. 3 ст. 18; п. 3 ст. 19; ст. 21; п. 2 ст. $22)$; Европейскую конвенцию о защите прав человека и основных свобод (ст.ст. 8-10).

Также можно отметить и ряд других актов международного характера, затрагивающих вопросы установления специальных административно-правовых режимов. Например, Резолюцию XXIX сессии Генеральной Ассамблеи ООН от 14 декабря 1974 г., где содержится положение, исходя из которого под агрессией против Российской Федерации может быть признано применение иностранным государством (группой государств) вооруженной силы против суверенитета, политической независимости, целостности и неприкосновенности территории России.

Следующий (после международных и конституционных норм) уровень правового регулирования административно-правовых режимов представлен федеральными конституционными и федеральными законами.

Как отмечается в литературе, «в законодательных актах устанавливается вид правового режима, его носитель, основания введения, субъект режимного управления, режимные правила (определяется, какого рода и от какого органа исполнительной власти необходимо получить разрешения на осуществление того или иного вида деятельности, какие действия подлежат обязательной регистрации или запрещаются без специального на то разрешения, какие виды ответственности предусмотрены за нарушение требований режима и др.)»²2.

При этом административно-правовые режимы могут являться как частью общих тематических законов, так и

${ }^{22}$ Попова Н.Ф. О классификации специальных административноправовых режимов // Вестник РГГУ. 2008. № 5. С. 41-42. 


\section{Право и политика $1(157) \cdot 2013$}

устанавливаться в специальных законодательных актах. Как подчеркивает Ю.А. Тихомиров: «Один или несколько специальных актов такого рода создают юридическую основу для серии конкретно-оперативных распорядительных указаний, приказов и распоряжений. Их связь и последовательность принятия и реализации крайне необходимы, поскольку в противном случае не удается обеспечить юридико-операциональную деятельность граждан и юридических лиц» ${ }^{23}$.

Так, например, в настоящее время правовой основой двух особых правовых режимов - о чрезвычайном и военном положении, вводимых в РФ в исключительных для государства обстоятельствах, являются такие специальные Федеральные конституционные законы (сокращенно - ФКЗ), как упоминавшийся ранее ФКЗ от 30 мая 2001 г. № 3-ФКЗ «О чрезвычайном положении» и ФКЗ от 30 января 2002 г. № 1-ФКЗ «О военном положении» (в ред. от 28.12. 2010) $)^{24}$.

ФКЗ «О чрезвычайном положении» (ст.ст. 16-27) и ФКЗ «О военном положении» (ст.ст. 9-15) закреплены и разграничены полномочия Президента РФ, федеральных органов исполнительной власти, органов исполнительной власти субъектов РФ, органов военного управления, иных структур и должностных лиц по введению и применению на территории, где введено чрезвычайное или военное положение, мер, связанных с временным ограничением отдельных прав граждан.

Но масштабы этих ограничений должны быть соразмерны природе и характеру обстоятельств. К примеру, именно такой подход закреплен в ст. 28 ФКЗ «О чрезвычайном положении», где определены пределы применения мер временных ограничений в условиях чрезвычайного положения, а также установлен исчерпывающий перечень конкретных ограничений прав и свобод на время чрезвычайного положения.

К числу общих тематических законов, содержащих нормы, регулирующие порядок установления того или иного административно-правового режима (в нашем случае, военного или чрезвычайного положения) можно отнести, например, Ф3 от 31.05.1996 №61-Ф3 «Об обороне» (в ред. от 08.12.2011) $)^{25}$, где впервые в российском законодательстве было дано определение военного положения как особого правового режима; Ф3 от 26.02.1997 г. №31-Ф3 «О мобилизационной подготовке и мобилизации в РФ» (в ред. от 09.03.2010 $)^{26}$, который устанавливает правовые основы

\footnotetext{
${ }^{23}$ Тихомиров Ю.А. Указ. соч. С. 537.

${ }^{24}$ Собрание законодательства РФ. 2002. №5. Ст. 375; 2011. №1. Ст.1.

${ }_{25}^{25}$ Собрание законодательства РФ. 1996. №23. Ст. 2750; 2011. №50. Ст. 7366 .

${ }^{26}$ Собрание законодательства РФ. 1997. №9. Ст. 1014; 2010 . №11. Ст. 1176 .
}

по обеспечению защиты государства от вооруженного нападения и удовлетворению потребностей государства и нужд населения в военное время.

Также следует отметить, что при осуществлении мер обеспечения различных административно-правовых режимов особое значение имеют федеральные законы, касающиеся соблюдения прав и свобод человека и гражданина уполномоченными органами. Например, Ф3 от 07.02.2011 №3-Ф3 «О полиции» (в ред. от 25.06.2012 г.) ${ }^{27}$, Ф3 от 03.04.1995 г. №40-Ф3 «О федеральной службе безопасности» (в ред. от 08.12.2011) ${ }^{28}$, Ф3 от 27.07.2004 №79Ф3 «О государственной гражданской службе РФ» (ред. от 21.11.2011) $)^{29}$, Ф3 от 02.03.2007 г. №25-Ф3 «О муниципальной службе в РФ» (в ред. от 21.11.2011) ${ }^{30}$ и др.

В то же время необходимо отметить, что без принятия необходимых подзаконных актов с целью конкретизации режимных правил, установленных соответствующим законом, обойтись невозможно. Так, в указах Президента РФ определяются меры по обеспечению важнейших государственно-правовых состояний (военного и чрезвычайного положения, мобилизации), территории их действия и другие вопросы (например, Указ Президента РФ от 11.07.2004 №868 «Вопросы Министерства РФ по делам гражданской обороны, чрезвычайным ситуациям и ликвидации последствий стихийных бедствий» (ред. от 13.11.2012) ${ }^{31}$ ). В постановлениях Правительства РФ детализируются общефедеральные режимы (например, Постановление Правительства РФ от 30.12.2003 г. № 794 «О Единой государственной системе предупреждения и ликвидации чрезвычайных ситуаций» (в ред. от 01.11.2012) ${ }^{32}$ ) и т.д.

Таким образом, становление законодательства об административно-правовых режимах (показано на примере специальных режимов - военного и чрезвычайного положения) берет свое начало еще в дореволюционной России. В годы советской власти законодательное закрепление данных видов административно-правовых режимов развивалось под влиянием постоянно возникавших социально-политических конфликтов и развертывания военных действий в

\footnotetext{
${ }^{27}$ Собрание законодательства РФ. 2011. №7. Ст. 900; 2012. №26. Ст. 3441.

${ }^{28}$ Собрание законодательства РФ. 1995. №15. Ст. 1269; 2011. №50. Ст. 7366 .

${ }^{29}$ Собрание законодательства РФ. 2004. №31. Ст. 3215; 2011 . №48. Ст. 6730

${ }^{30}$ Собрание законодательства РФ. 2007. №10. Ст. 1152; 2011. №48. Ст. 6730.

${ }^{31}$ Собрание законодательства РФ. 2004. №28. Ст. 2882; 2012. №47. Ст. 6455 .

${ }^{32}$ Собрание законодательства РФ. 2004. №2. Ст. 121; 2012. №46. Ст. 6339.
} 
период ВОВ. В дальнейшем, многие правовые акты, предусматривавшие введение режимов чрезвычайного и военного положений, были приняты на рубеже 80-90 гг. $\mathrm{XX}$ столетия в связи с резким обострением социальных, политических, межнациональных отношений.

На современном этапе развитие законодательства о специальных административно-правовых режимах основывается, прежде всего, на общепризнанных международно-правовых и конституционных положениях, которые дают первичную легализацию режимов, а также устанавливают основания и принципы «режимных» ограничений прав и свобод человека и гражданина.

По юридической природе среди правовых актов, регулирующих административно-правовые режимы, можно выделить правоустанавливающие, которые содержат первичные «режимные» нормы, и правоприменительные акты. Помимо международных актов и Конституции РФ, к правоустанавливающим относятся общетематические и специальные законы, которые определяют вид правового режима, его носителей, основания введения, субъектов, осуществляющих режимное управление, режимные меры и правила деятельности. Среди правоприменительных актов выделяются указы Президента РФ, постановления Правительства РФ и др. подзаконные акты, устанавливающие конкретные меры реализации административно-правовых режимов.

\section{Библиография:}

1. Попова Н.Ф., Попова Н.Н. Специальные административно-правовые режимы. Монография. М.: ВНИИ МВД России. 2008. 144 с.

2. Фомин А.А. Исторические этапы развития чрезвычайного законодательства в России (конец XIX - XX вв.) // История государства и права. 2006. №3. С. 76-84.

3. Демичев Д.М. Правовые проблемы преодоления последствий чернобыльской катастрофы // Государство и право. 1998. № 1. С. 15.

4. Агабалаев М.И. Особенности классификации административно-правовых режимов обеспечения общественной безопасности // Современная наука: Актуальные проблемы теории и практики. 2012. №1. C. 13-15.
5. Тихомиров Ю.А. Административное право и процесс: полный курс. М.: Изд-во Тихомирова М.Ю., 2005. C. 540.

6. Бахрах Д.Н. Административное право: Учебник для вузов. М.: Бек, 1996. С. 202.

7. Благов А.Д. сущность и особенности административно-правового режима // Известия ИЭГА. 2007. №2 (52). С. 128.

8. Попова Н.Ф. О классификации специальных административно-правовых режимов // Вестник РГГУ. 2008. № 5. C. 39.

\section{References (transliteration):}

1. Popova N.F. O klassifikatsii spetsial'nykh administrativno-pravovykh rezhimov // Vestnik RGGU. 2008. № 5. S. 41-42.

2. Popova N.F., Popova N.N. Spetsial'nye administrativnopravovye rezhimy. Monografiya. M.: VNII MVD Rossii. 2008. $144 \mathrm{~s}$

3. Vedomosti S'ezda narodnykh deputatov RSFSR i Verkhovnogo Soveta RSFSR. 1991

4. Fomin A.A. Istoricheskie etapy razvitiya chrezvychaynogo zakonodatel'stva v Rossii (konets XIX - XX vv.) // Istoriya gosudarstva i prava. 2006. №3. S. 76-84.

5. Demichev D.M. Pravovye problemy preodoleniya posledstviy chernobyl'skoy katastrofy // Gosudarstvo i pravo. 1998. № 1. S. 15.

6. Sobranie zakonov i rasporyazheniy Raboche-krest'yanskogo Pravitel'stva Soyuza SSR. 1925

7. Agabalaev M.I. Osobennosti klassifikatsii administrativno-pravovykh rezhimov obespecheniya obshchestvennoy bezopasnosti // Sovremennaya nauka: Aktual'nye problemy teorii i praktiki. 2012. №1. S. 13-15.

8. Tikhomirov Yu.A. Administrativnoe pravo i protsess: polnyy kurs. M.: Izd-vo Tikhomirova M.Yu., 2005. S. 540.

9. Bakhrakh D.N. Administrativnoe pravo: Uchebnik dlya vuzov. M.: Bek, 1996. S. 202.

10. Blagov A.D. sushchnost' i osobennosti administrativnopravovogo rezhima // Izvestiya IEGA. 2007. №2 (52). S. 128.

11. Popova N.F. O klassifikatsii spetsial'nykh administrativno-pravovykh rezhimov // Vestnik RGGU. 2008. № 5. S. 39. 